\title{
Does type of prosthesis affect long-term outcomes after aortic valve replacement for infective endocarditis? How should we properly answer this question?
}

\author{
Ko Bando, MD, PhD
}

From the Department of Cardiac Surgery, The Jikei University School of Medicine, Tokyo, Japan.

Disclosures: Author has nothing to disclose with regard to commercial support.

Received for publication Oct 26, 2016; accepted for publication Oct 27, 2016; available ahead of print Dec 16, 2016.

Address for reprints: Ko Bando, MD, PhD, Department of Cardiac Surgery, The Jikei University School of Medicine, 3-25-8 Nishi Shinbashi, Minato-ku, Tokyo 105-8461, Japan (E-mail: kobando@ jikei.ac.jp).

J Thorac Cardiovasc Surg 2017; 153:829-30

0022-5223/\$36.00

Copyright (C) 2016 by The American Association for Thoracic Surgery

http://dx.doi.org/10.1016/j.jtcvs.2016.10.045

The surgical treatment of active infective endocarditis (IE) is challenging, and the type of prosthesis to be implanted during the active phase remains controversial. ${ }^{1-3}$ Because of major concerns regarding the use of foreign artificial materials such as conventional mechanical or stented bioprosthetic valves, homografts have been advocated for their favorable long-term outcomes, especially in cases involving prosthetic valve endocarditis (PVE), aortic annular disruption, fistula, or abscess. ${ }^{4,5}$

Kim and colleagues ${ }^{6}$ challenged this surgical dogma and report a 2-institution retrospective study comparing early and late outcomes among homografts, xenografts (bioprostheses), and mechanical valves. They conclude that no significant benefits of using homografts were demonstrated in terms of resistance to reinfection in the setting of aortic valve IE.

European homograft experts criticized this large-scale retrospective review because of the relatively short follow-up period, large number $(20 \%)$ of patients lost to follow-up, and significant imbalance in indications for homograft use. ${ }^{7}$ They reiterated the advantage of homografts, especially for severe types of aortic valve IE, including PVE, annular abscess, fistula, and disruption. ${ }^{7}$ Although the homograft implantation outcomes reported by Nappi and colleagues ${ }^{7}$ were excellent, other surgical teams have reported that the implantation of conventional prostheses during the active phase of aortic valve endocarditis provide similar outcomes as aortic homografts, even in patients with annular abscess. ${ }^{2,8}$ Moreover, several reports have raised concerns regarding early mortality and morbidity ${ }^{9}$ as well as the high mortality rate in reoperations for homograft endocarditis. $^{10}$

How should this question be properly answered? The Society of Thoracic Surgeons guidelines recommend the following ${ }^{11}$ :

1. When periannular abscess is associated with IE, it is reasonable to use a mechanical or stented tissue valve

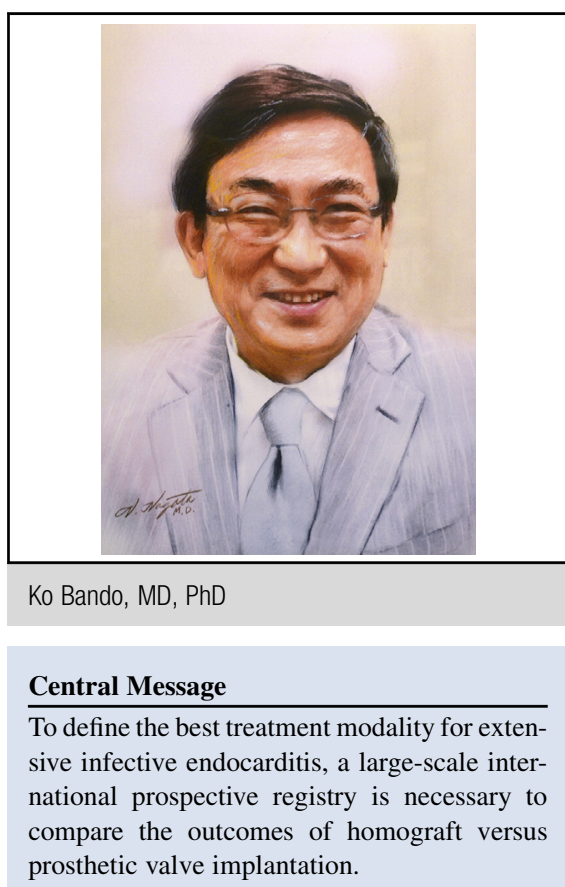

See Article page 824 .

if radical debridement is carried out and the valve can be anchored to healthy and strong tissue (Class IIa, Level of evidence B).

2. Aortic homografts are considered reasonable for native aortic valve endocarditis particularly with "periannular abscess and extensive annular or aortic wall destruction requiring aortic root replacement/reconstruction or extensive aortic-ventricular discontinuity" (Class IIb, Level of evidence B).

Both of these recommendations are categorized as Class II, indicating that there is conflicting evidence and/or a divergence of opinion related to the usefulness/efficacy of a procedure or treatment. The usefulness/efficacy of aortic homograft is less well established by evidence/opinion (categorized as Class IIb) because data are derived from a single randomized trial or from nonrandomized studies (Level of evidence B).

No surgeon argues that "a mechanical or stented tissue valve is reasonable in native aortic valve endocarditis if the infection is limited to the native aortic valve or to the aortic annulus." ${ }^{11}$ As such, we should focus on the severe 
types of IE, including PVE and extensive IE associated with periannular abscess, extensive aortic wall destruction, or aortic-ventricular discontinuity. Only a large-scale, international prospective registry with long-term complete followup to compare homograft implantation versus prosthetic valve implantation associated with radical debridement of infected tissue followed by appropriate reconstruction of the aortic root with bovine pericardium can answer this critical question.

\section{References}

1. David TE, Gavra G, Feindel CM, Regesta T, Armstrong S, Maganti MD. Surgical treatment of active infective endocarditis: a continued challenge. J Thorac Cardiovasc Surg. 2007; 133:144-9.

2. Nguyen DT, Delahaye F, Obadia JF, Duval X, Selton-Suty C, Carteaux JP, et al. Aortic valve replacement for active infective endocarditis: 5-year survival comparison of bioprostheses, homografts and mechanical prostheses. Eur J Cardiothorac Surg. 2010;37:1025-32.

3. Savage EB, Saha-Chaudhuri P, Asher CR, Brennan JM, Gammie JS. Outcomes and prosthesis choice for active aortic valve infective endocarditis: analysis of The Society of Thoracic Surgeons adult cardiac surgery database. Ann Thorac Surg. 2014;98:806-14.
4. Yankah AC, Klose H, Petzina R, Musei M, Siniawski H, Hetzer R. Surgical management of acute aortic root endocarditis with viable homograft; 14-year experience. Eur J Cardiothorac Surg. 2002;21:260-7.

5. Sung K, Lee YT, Park PW, Jun TG, Yang JH. Minimizing foreign material in the reconstruction of infected complex annuloaortic disruption. Ann Thorac Surg. 2004;78:2191-2.

6. Kim JB, Ejiofor J, Yammine M, Camuso JM, Walsh CW, Ando M, et al. Are homografts superior to conventional prosthetic valves in the setting of infective endocarditis involving the aortic valve? J Thorac Cardiovasc Surg. 2016;151: 1239-46.

7. Nappi F, Spadaccio C, Acar C. Use of allogenic tissue to treat infective valvular disease. Has everything been said? J Thorac Cardiovasc Surg. 2017; 153:824-8.

8. Avierinos JF, Thuny F, Chalvignac V, Giorgi R, Tafanelli L, Casalta JP, et al. Surgical treatment of active aortic endocarditis: homografts are not the cornerstone of outcome. Ann Thorac Surg. 2007;84:1935-42.

9. Perrotta S, Aljassim O, Jeppsson A, Bech-Hanssen O, Svensson G. Survival and quality of life after aortic root replacement with homograft in acute endocarditis. Ann Thorac Surg. 2010;90:1862-7.

10. Kaya A, Schepens MA, Morshus WJ, Heijmen RH, De La Riviere AB, Dossche KM. Valve-related events after aortic root replacement with cryopreserved aortic homografts. Ann Thorac Surg. 2005;79:1491-5.

11. Byrne JG, Rezai K, Sanchez JA, Bernstein RA, Okum E, Leacche M, et al. Surgical management of endocarditis: the Society of Thoracic Surgeons clinical practice guideline. Ann Thorac Surg. 2011;91:2012-9. 